\title{
Model Pembelajaran Quantum Teaching Tipe TANDUR Berbantuan Permainan Tradisional Terhadap Hasil Belajar IPA
}

\author{
Inggit Pragasuri Subakthi Putri¹, N. Dantes ${ }^{2}$, K. Suranata ${ }^{3}$
}

${ }^{1}$ Program studi Pendidikan Guru Sekolah Dasar, Universitas Pendidikan Ganesha, Singaraja, Indonesia

${ }^{23}$ Program studi Bimbingan Konseling, FIP, Universitas Pendidikan Ganesha, Singaraja, Indonesia

\author{
A R T I C L E I N F O \\ Article history: \\ 1 Maret 2020 Received in \\ revised form \\ 30 Maret 2020 \\ Accepted 11 April 2020 \\ Available online 15 \\ Mei 2020 \\ Kata Kunci: \\ Quantum teaching, \\ permainan tradisional, IPA. \\ Keywords:quantum \\ teaching, traditional game, \\ natural science
}

\begin{abstract}
A B S T R A K
Tujuan dari penelitian ini yaitu mengetahui implementasi model pembelajaran quantum teaching tipe TANDUR berbantuan pemainan tradisional terhadap hasil belajar IPA siswa kelas IV SD. Jenis penelitian yang dilaksanakan yaitu quasi eksperiment dirancang dengan Non Equivalen Post-Test Only Kontrol Grup Desain. Adapun populasi dalam penelitian ini adalah seluruh kelas IV SD Gugus V Kecamatan Buleleng dan terdiri dari 5 kelas. Sampel ditentukan dengan menggunakan teknik random sampling. Sampel penelitian ini terdiri SDN 1 Petandakan yang terdiri dari 28 siswa (eksperimen) dan SDN 1 Nagasepaha yang terdiri dari 31 siswa (kontrol). Data hasil belajar IPA dikumpulkan dengan objektif sebanyak 30 soal. Analisis data melalui tahap analisis statistik deskriptif dan inferensial. Hasil penelitiaan ini menunjukkan yaitu nilai hitung sebesar 3.21 dan nilai tabel sebesar 2.0. Artinya bahwa thitung lebih besar dibandingkan dengan $t_{\text {tabel }}$. Dapat disimpulkan dengan, terdapatnya pengaruh dari hasil belajar IPA antara kelompok siswa yang dibelajarkan
\end{abstract} menggunakan model pembelajaran quantum teaching tipe TANDUR berbantuan pemainan tradidional dengan peserta didik yang menggunakan pendekatan saintifik pada siswa kelas IV SD di Gugus V Kecamatan Buleleng Tahun Ajaran 2019/2020.

\begin{abstract}
A B S T RA C T
The purpose of this research was to find out the implementation of quantum teaching learning model type TANDUR assisted with traditional game toward the students'natural science learning outcomes on fourth grade elementary school students. The type of this research was quasi experimental designed with Non Equivalent Post-Test Only Control Group Design. The population in this research was all fourth grade elementary school students of Cluster $V$ Buleleng District and it consisted of 5 classes. The sample was determined by using random sampling technique. The sample of this research was SDN 1 Petandakan consisted of 28 students as experimental group and SDN 1 Nagasepaha consisted of 31 students as control group. The natural science learning outcome was collected by using 30 multiple choice questions. The data was analyzed through descriptive and inferential statistic analysis. The results of this research showed that the $t_{\text {count }}$ was 3.21 and $t_{\text {table }}$ was 2.0. it meant that $t_{\text {count }}$ was higher than $t_{\text {table. }}$. It could be concluded that there was an effect on natural science learning outcome between the groups of students who were taught by using quantum teaching learning model type TANDUR assisted with traditional game with students who were taught by using scientific approach on fourth grade elementary school students in Cluster V, Buleleng District in academic year 2019/2020.
\end{abstract}

\section{Pendahuluan}

Menjadi manusia yang berkulitas yang mampu bersaing dengan sumber daya manusia yang ada di dunia adalah tantangan di era sekarang ini. Perkembangan di era revolusi 4.0 mengharuskan manusia untuk menguasai kemapuan 4C (critical thingking, colaboration, communication, and creativitas). Empat 
kemampuan itu tidak didapat secara langsung melainkan dengan proses pendidikan yang berkualitas. Pendidikan adalah suatu proses sadar yang direncanakan secara sistematis untuk membatu anak mengembangkan potensi yang dimiliki dengan cara latihan, bimbingn dan belajar sehingga tujuan pembelajaran tercapai (UU No 20 tahun 2003). Pendidikan dibedakan menjadi tiga yaitu pendidikan formal, pendidikan Informal dan pendidikan no-formal. Pendidikan formal adalah pendidikan yang dilakukan dan direncanakan secara terprogram dan tentunya terdapat aturan dan kurikulum yang harus dilaksankan yang sesuai dengan jenjang pendidikan, serta waktu sudah ditentukan. Salah satu contoh pendidikan formal adalah SD. Pelajaran yang diberikan di sekolah dasar salah satunya adalah pelajaran IPA.

Malawi \& Juwarti (2013:6) menyatakan bahwa Ilmu pengetahuan alam yaitu berasal dari Bahasa Inggris yang terjemahan kata-kata yaitu natural science, yang artinya ilmu pengetahuan alam (IPA). IPA merupakan ilmu pengetahuan yang mempelajari tentang peristiwa-peristiwa yang terjadi di alam semesta. Baik ilmu pengetahuan yang mempelajari tentang benda mati maupun yang tidak mati dengan jalan melakukan pengamatan. Pembelajaran sains di sekolah dasar dikenal dengan mata pelajaran IPA yang masih menyatu dan diajarkan secara terpadu, dalam artian belum diajarkan secara terpisah seperti biologi, fisika dan kimia (Supramono, 2016). Pembelajaran IPA tidak hanya mengajarkan penguasaan fakta, konsep dan prinsip tentang alam tetapi juga mengajarkan metode memecahkan masalah, melatih kemampuan berpikir kritis dan mengambil kesimpulan melatih bersikap objektif, bekerjasama dan menghargai pendapat orang lain. Model pembelajaran IPA yang sesuai untuk anak usia sekolah dasar adalah model pembelajaran yang menyesuaikan situasi belajar siswa dengan situasi kehidupan nyata di masyarakat. Siswa diberi kesempatan untuk menggunakan alat-alat dan media belajar yang ada di lingkungannya dan menerapkannya dalam kehidupan sehari-hari (Usman Samatowa, 2006: 11-12).

Kondisi pembelajaran IPA SD di lapangan belum sesuai dengan kondisi ideal. Adapaun terlihat beberapa masalah suatu pembelajaran IPA di lapangan, yaitu peserta didik jarang untuk menggunakan imajinasi atau daya nalarnya, tetapi mereka hanya terbiasa dengan cara lama yaitu menghafal. Hal ini juga didukung dengan hasil observasi yang dilakukan, Hasil wawancara yang didapatkan yaitu: (1) siswa lebih aktif jika diajak belajar sambil bermain oleh guru, (2) siswa hanya sekedar dalam melakukan proses pembelajaran yang diberikan guru, hanya seperti angin lalu, (3) kebanyakan siswa harus dipaksa oleh guru dalam menjawab pembelajaran agar mau ikut berpartisipasi, (4) nilai siswa kelas IV dalam mata pelajaran IPA masih rendah, (5) ada beberapa siswa yang bisa menjawab tetapi malu untuk mengungkapkan kepada teman-teman yang lainnya, (6) kurangnya pemahaman siswa dalam mata pelajaran IPA, (7) kurangnya pengalaman siswa dalam pembelajaran yang bersentuhan langsung dengan lingkungan. Selanjutnya, dilakukan kegiatan observasi pada hari jumat, 18 sampai 22 Oktober 2019, dengan cara pencatatan dokumen khususnya pada mata pelajaran IPA. Dari pencatatan dokumen yang diperoleh, yaitu pada kelas IV Sekolah Dasar Gugus V Kecamatan Buleleng berupa nilai hasil ulangan tengah semester (UTS) memperlihatkan hasil pelajaran IPA kelas IV terbilang rendah. Dari beberapa permasalahanpyang dipaparkan terdapat faktor yang menyebabkan terjadinyajhal tersebut salah satunya kurangnya pengalaman/suasana barupuntuk siswa dalam proses pembelajaran dan menyebabkan kurangnya minat siswa sehingga hasil belajar IPA siswa menjadi kurang baik.

Hasil belajar adalah suatu titik dalam mengetahui kepuasan dalam mengikuti suatu program pendidikan agar tercapainya tujuan pendidikan yang ditetapkan dengan meliputi 3 aspek (Bundu, 2006:17). Hasil belajar adalah sebuah tindakan evaluasi tentang aspek berpikir (kognitif), aspek sikap (afektif) dan kemapuan keterampilan (psikomotor) yang ada pada anak setelah melakukan proses pembelajaran (Sudijono, 2006). Hasil belajar adalah hasil dari sebuah peroses interaksi dari proses belajar dan mengajar untuk tercaipanya tujuan pembelajaran (Slameto, 2013; Maisaroh \& Rostrieningsih, 2010). Hasil belajar adalah kemampuan yang dimiliki oleh siswa setelah proses belajar, tujuan utama hasil belajar adalah untuk mengetahui sebatas mana siswa berhasil dalam memahami serta mengerti materi yang diberikan dalam proses pembelajaran (Devi dan Lilis, 2018). Faktor-faktor yang mempengaruhi belajar adalah faktor intern (dari dalam) diri siswa dan faktor ekstern (dari luar) siswa. Berkaitan dengan faktor dari dalam diri siswa, selain faktor kemampuan, ada juga faktor lain yaitu motivasi, minat, perhatian, sikap, kebiasaan belajar, ketekunan, kondisi sosial ekonomi, kondisi fisik dan psikis. Kehadiran faktor psikologis dalam belajar akan memberikan andil yang cukup penting. Faktorfaktor psikologis akan senantiasa memberikan landasan dan kemudahan dalam upaya mencapai tujuan belajar secara optimal. Hasil penelitian yang dilakukan oleh Budi dan Lukad (2016) menyatakan bahwa penguasaan metode mengajar, media pembelajarajaran yang digunakan guru dan motivasi guru secara bersama-sama dapat mempengaruhi hasil belajar siswa. 
Berdasarkan masalah serta pejabaran di atas dapat dikatakan bahwa pemilihan model dan metode oleh guru adalah salah satu faktor penentu keberhasilhan proses pembelajaran. Salah satu model yang bisa digunakan oleh guru adalah Model Pembelajaran Quantum Teaching tipe TANDUR. Model Pembelajaran Quantum Teaching menurut (DePoter, 2010:32) mengatakan bahwa Quantum teaching adalah suatu pengubahan gaya belajar yang meriah, dengan segala bentuk nuansanya. Quantum teaching adalah sebuah cara mengajar siswa yang aktif dan selalu ingin tampil pada saat pembelajaran karena dalam model pembelajaran quantum teaching ini akan lebih mengaktifkan indra mulai dari melihat, mendengar dan berbicara (Yahya, 2017). Model quatum teaching mempunyai beberapa prinsip, menurut Dwi, Yahya, Ardian, (2019) prinsipnya antara lain: 1) semua orang berbicara, 2) semuanya terlibat dalam proses pembelajaran serta semua sumber belajar digunakan, 3) semua proses belajar mempunyai tujuan yang jelas, 4) pemberian sebuah sebuah rangsangan sangat penting dalam proses menumbuhkan rasa ingin tahu, hal ini lebih baik diberikan sebelum proses namai. 5) Akui setiap usaha. Apapun hasil yang ditunjukkan oleh siswa harus tetap di akui. 6) perayaan dalam proses pembelajaran adalah salah satu umpan balik yang bisa diberikan.

Menurut (DePoter, 2010:32) Quantum teaching mempunyai kerangka yaitu disebut TANDUR: Tumbuhkan, Alami, Namai, Demonstrasi, Ulangi dan Rayakan. 1) Tumbuhkan, Tahap menumbuhkan yaitu pada gairah siswa untuk melaksanakan pembelajaran yang dipacu oleh guru, agar semangat semua siswa sama rata dan kelas menjadi hidup; 2) Alami, Tahap alami merupakan pada situasi ini siswa dituntut agar mengeluarkan pengetahuan awal yang mereka miliki sebelum masuk ke dalam kelas. Tahap alami bisa dilakukan dengan mengadakan pengamatan, guru dapat juga mengetahui gaya belajar siswa yakni ada auditori, visual, dan kinestetik; 3) Namai, Tahap namai merupakan tahap guru yang lebih dominan dalam mengembangkan suatu konsep-konsep yang ada. Tahap ini memicu keterampilan kognitif siswa untuk mengaitkan apa yang telah dipikirkan dengan konsep-konsep yang telah diberikan oleh pengajar; 4) Demonstrasi, Tahap demonstrasi yaitu tahap siswa untuk sharing pengetahuan yang ia peroleh ke hadapan seluruh teman kelas dan juga guru. Tahap demonstrasi bisa dilakukan melalui permainan, menjawab pertanyaan, dan menunjukkan hasil pekerjaan; 5) Ulangi, Tahap ulangi, yaitu tahap untuk guru mampu mempertegas materi-materi yang telah diberikan; 6) Rayakan, Tahap Rayakan merupakan aktivitas pengajar untuk memberikan sebuah reward kepada peserta didik dalam mengikuti proses pembelajaran.

Menurut (DePoter, 2010:32) dalam Wahyu, dkk. (2016) menyatakan bahwa quantum teaching mempunyai kelebihan yaitu 1) model quantum teaching memberikan kesempatan kepada siswa untuk belajar sesaui dengan yang diinginkan. 2) model quantum teaching ini mengaitkan proses belajaran dengan apa yang dialami oleh siswa sehingga memberikan manfaat yang baik untuk siswa. 3) model quantum teaching mengajak siswa untuk aktif untuk melaksanakan pembelajarannya ini dapat dilihat dari segala geitan dalam proses pembelajaran baik itu memilih ide dalam proses pembelajaran sampai dengan evaluasi. dan 4) memberikan rasa nyaman siswa melalui penataan lingkungan belajar dengan mengatur posisi meja dan kursi dengan format yang dinamis. Hal lain yang lebih menonjol dari model Quantum Teaching terletak pada delapan kunci keunggulan yang juga digunakan dalam Quantum Teaching ini, yaitu: integritas (kejujuran), kegagalan awal kesuksesan, berbicara dengan niat yang positif, hidup di saat ini, komitmen, tanggung jawab, sikap luwes atau fleksibel, dan keseimbangan antar pikiran, tubuh dan jiwa.

Banyak penelitian yang sudah dilakukan yang berkaitan dengan model quantum teaching antara lain pada penelitian yang berjudul Penerapan model quantum teaching untuk meningkatkan kualitas pembelajaran pada mata pelajaran IPS kelas V MI Islamiyah Kebonsari Kota Malang oleh Evy Rosalina Susanti yaitu hasil penelitian menunjukkan bahwa penerapan model Quantum Teaching pada pembelajaran IPS telah berhasil meningkatkan hasil belajar siswa kelas V MI Islamiyah Kebonsari. Hal ini dilihat dari perolehan hasil belajar siswa terus meningkat mulai dari rata-rata sebelumnya $(65,15)$ mengalami paningkatan pada siklus I dengan rata-rata kelas sebesar $(70,90)$ dan prosentase ketuntasan belajar kelasnya yaitu $(68,75)$ meningkat pada siklus II dengan rata-rata kelasnya sebesar $(80,56)$ dan prosentase ketuntasan belajar kelasnya sebesar (81,25\%). Disarankan untuk peneliti selanjutnya dapat memperbaiki kelemahan-kelemahan yang ada sehingga pembelajaran diharapkan berjalan seoptimal mungkin. Adapun hasil penelitian model quantum teaching yang berkaitan dengan permainan tradisional yaitu pada penelitian yang berjudul Pembelajaran Treffinger Berbantuan Permainan Tradisional Congklak Untuk Meningkatkan Kemampuan Komunikasi Matematis oleh Himmatul Ulya dan Ratri Rahayu yang memperoleh hasil yaitu adanya peningkatan kemampuan komunikasi matematis peserta didik pada kategori rendah sebanyak 4 peserta didik (9,76\%), kategori sedang sebanyak 16 peserta didik (39,02\%), dan kategori tinggi sebanyak 21 peserta didik (51,22\%). Secara klasikal peningkatan kemampuan komunikasi matematis peserta didik sebesar 0,65 atau 65\% yang berarti bahwa rata-rata peningkatan kemampuan komunikasi matematis peserta didik termasuk dalam kategori sedang. 
Selain penggunaan model pembelajaran, pilihan metode juga sangat penting dalam proses pembelajaran adalah pemeilihan metode pembelajaran. Mengingat anak SD ada pada fase bermain, maka asalah satu metode yang bisa digunakan adalah metode permainan tradisional. Sudirjo (2017) mengemukakan bahwa pada umur 6 sampai 12 tahun, anak sudah mulai ada keinginan untuk keluar rumah dan bermain dengan temannya melalui permainan-permainan yang melibatkan aktivitas fisik. Menurut James Danandjaja (dalam (Azizah, 2016:284) mengatakan bahwa permainan tradisional adalah kreasi nusa bangsa untuk anak-anak yang telah diwarisi oleh nenek moyang kita. Permainan tradisional adalah salah satu sarana bermain anak, yang bermanfaat bagi kesehatan, kebugaran dan tumbuh kembang anak, terdapat nilai-nilai positif yang terkandung dalam permainan yaitu kerjasama, kejujuran, tolong menolong, tanggung jawab dan lain sebagainya. (Mega, baitul dan Arif, 2018). Selain itu, permainan tradisional lebih efektif dari kegiatan sehari-hari dalam rangka untuk mengembangkan kontrol objek, kemampuan lokomotor dan keterampilan dasar (Hakimeh Albari dkk, 2009: 126). Permainan tradisional yang terstruktur sedemikian rupa secara langsung mempengaruhi psikomotor, perkembangan kognitif dan emosional anak. Adapun menurut Dilanisa (2011:5), permainan tradisional merupakan permainan daerah yang tiap daerahnya memiliki tata cara dan permainan yang berbeda-beda. Permainan tradisional yang digunakan memiliki unsur tersendiri dalam penggunaanya, permainan yang dipilih nanti akan menyesuaikan dengan materi IPA yang akan diterangkan oleh pengajar. Anak-anak menjadi tidak jenuh dalam menerima proses pembelajaran dan bisa bermain dengan teman sekaligus belajar. Hal ini akan memperbaiki kualitas belajarrsiswa, pastinya hasil belajar siswa menjadi optimal.

Penelitian ini difokuskan pada penelitian tentang pengaruh ModelhPembelajaran QuantumkTeaching tipe TANDUR Berbantuan Permainan Tradisional terhadap Hasil Belajar IPA siswa kelas IV Gugus V Kecamatan Buleleng Tahun Ajaran 2019/2020. Adapun tujuan penelitian ini adalah untuk mengetahui pengaruh implementasi model pembelajaran quantum teaching tipe TANDUR berbantuan permainan tradisional terhadap hasil belajar IPA siswa kelas IV SD Gugus V, Kecamatan Buleleng Tahun Pelajaran 2019/2020.

\section{Metode}

Penelitian ini dilaksanakan di SD Gugus V Kecamatan Buleleng. Pada Gugus V ini, terdapat lima Sekolah Dasar yang diantaranya adalah SD N 1 Sari Mekar, SD N 2 Sari Mekar, SD N 1 Nagasepaha, SD N 1 Petandakan dan SD N 2 Petandakan. Adapun waktu pelaksanaan penelitian ini dilaksanakan pada semester genap tahun pelajaran 2019/2020.

Penelitian ini menggunakan eksperimennsemu (quasiiexperiment). Dalam eksperimen semu ini yaitu dapat membandingkan dua jenis model pembelajaran yaitu model pembelajaran quantum teaching berbantuan permainan tradisional dengan pendekatan saintifik, dan masing-masing model tersebut mempunyai suatu pengaruh terhadap satu variabel terikatnya (hasil belajar IPA yang terfokus pada ranah kognitif siswa).

Populasi merupakan perkumpulan dari anggota-anggota dalam suatu penelitian yang terbentuk dari suatu kelompk orang, kejadian, atau objek-objek yang telah ditentukan (Maolani \& Cahyana, 2016:39). Populasi dalam penelitian ini adalah seluruh siswa kelas IV di gugus V Kecamatan Buleleng tahun ajaran 2019/2020. Gugus ini terdiri dari lima sekolah, yaitu SDN 1 Sari Mekar, SDN 2 Sari Mekar, SDN 1 Nagasepaha, SDN 1 Petandakan dan SDN 2 Petandakan. Sehingga terdapat 5 kelas IV dengan jumlah sebanyak 123 orang siswa. Untuk mengetahui tingkat kesetaraan tersebut terhadap populasi sampel dalam penelitian ini dilakukan uji kesetaraan dengan menggunakan ANAVA satu jalur, (Koyan, 2012:42)

Menurut Agung, (2016:8) Sampel merupakan bagian dari populasi yang terkena secara sengaja dan langsung pada penelitian. Berdasarkan data tabel diatas dengan jumlah populasi di gugus V Kecamatan Buleleng terdapat lima SD yaitu akan didapatkan sampel keseluruhan. Teknik pengambilan sampelddalam penelitiannini adalah teknik random sampling yang di random adalah kelas sebagai intax group. Teknik ini dilakukan dengan cara undian. Semua kelas IV di Gugus V Kecamatan Buleleng diundi untuk mendapatkan kelasssampel, semua kelas berkesempatan untuk menjadi kelasssampel. Pengundian pertama menentukan sampel, lalu pengundian terakhir yang dilakukan adalah untuk memperoleh kelas eksperimen dan kelas kontrol.

Berdasarkan hasil undian yang didapatkan, kelas IV SDN 1 Petandakan sebagai kelas eksperimen dengan jumlah siswa sebanyak 28 orang dan kelas IV SDN 1 Nagasepaha menjadi kelas kontrol dengan jumlah siswa sebanyak 31 orang. Kelas eksperiment diberikan perlakuan dengan menerapkan model pembelajarannquantum teaching tipe TANDUR berbantuan permainan tradisional dan kelas kontrol diberikan perlakuan dengan pembelajaran pendekatan saintifik. Dalam penelitian ini yang menjadi 
variabel bebas adalah model quantum teaching tipe TANDUR berbantuan permainan tradisional $(\mathrm{X})$ dan yang menjadi variabel terikat adalah hasil belajar IPA (Y).

Data yang dikumpulkan dalam penelitian ini terdiri data hasil belajar IPA siswa dalam ranah kognitif. Data hasilkbelajar IPA dalam ranah kognitif. Sebelum tes digunakan dalam post-test dilakukan pengujian instrument meliputi uji valitditas isi, butir, uji reliabilitas, uji daya beda, uji tingkat kesukaran tes, dan uji efektifitas pengecoh. Pengujian instrument penelitian bertujuan untuk mendapat gambaran empieris apakah seluruh istrumen layak untuk digunakan sebagai instrument penelitian. Jadi tes harus benar-benar sepadan atau paralel degan materi pembelajaran (Candiasa, 2010:22). Proses uji coba menggunakan sebanyak 35 soal pilihan ganda. Setelah dilakukan uji coba dan dianalisis maka, soal yang digunakan untuk post-test sebanyak 30 soal pilihan ganda.

Analisis data dilakukan dengan analisis deskriptif dan analisis inferensial. Analisis deskriptif terdiri dari mean, standar deviasi dan varians. Skor rata-rata (mean) tiap variabel dikonversikan dengan menggunakan kriteria rata-rata ideal (Xi) dan standar deviasi ideal (SDi) dalam memenuhi untuk menentukkan tinggi atau rendahnya hasil belajar siswa. Dalam skala ini terdapat sebuah klasifikasi yang memerlukan sebuah mean dan standar devisasi. Untuk menentukan tinggi-rendahnya kualitas variabelvariabel tersebut, skor rata-rata (mean) setiap variabelkdikonversikan dengan menggunakan kriteria rata-rata idela $\left(\mathrm{X}_{\mathrm{i}}\right)$ dan standarkdeviasi ideal $\left(\mathrm{Sd}_{\mathrm{i}}\right)$ melalui skala hitung.

Tabel 1. Skala Lima dengan Penilaian Acuan Ideal Teoritik (PAIT)

\begin{tabular}{ccc}
\hline No & Kriteria & Klasifikasi \\
\hline 1 & $M_{i}+1,5 S D_{i}<M \leq M_{i}+3,0 S D_{i}$ & Sangat Tinggi \\
2 & $M_{i}+0,5 S D_{i}<M \leq M_{i}+1,5 S D_{i}$ & Tinggi \\
3 & $M_{i}-0,5 S D_{i}<M \leq M_{i}+0,5 S D_{i}$ & Sedang \\
4 & $M_{i}-1,5 S D_{i}<M \leq M_{i}-0,5 S D_{i}$ & Rendah \\
5 & $M_{i}-3,0 S D_{i} \leq M \leq M_{i}-1,5 S D_{i}$ & Sangat Rendah \\
\hline
\end{tabular}

(Koyan, 2012:25)

Analisis inferensial yaitu uji prasyaratkanalisis dan uji hipotesis. Adapun uji prasyaratkanalisis dalam penelitian ini terdiri dari ujiknormalitas sebaran data, ujikhomogenitas varians, dan uji korelasikantar variabelkterikat. Uji normalitas dalam penelitian dengan analisis Chi-Khuadrat, uji normalitas sebaran data dengan menggunkan analisis Chi-Kuadrat. "Jika $\mathrm{x}^{2}$ hitung $<\mathrm{x}^{2}$ tabel, maka H0 diterima, maka sampel yang berasal dari populasi yang berdistribusi normal” ((Dantes, 2017:,34). Uji homogenitas varians dengan menggunakan uji Fisher (F). setelah mengethaui hasil uji prasyarat analisis baru diadakan uji hipotesis penelitian dengan digunakan rumus $t$-test separated varians. Kriteria dalam pengujian ini pengujian adalah: jika $\mathrm{F}_{\text {hitung }}<\mathrm{F}_{\text {tabel }}$ maka keduakkelompok data homogen. Sebaliknya jika $\mathrm{F}_{\text {hitung }}<\mathrm{F}_{\text {tabel, }}$, maka kedua kelompok data tidakkhomogen (heterogen).

Penjabaran hipotesis sebagai berikut: $\mathrm{H}_{0}=$ Tidak terdapat pengaruh yang signifikan implementasi model pembelajaran quantum teaching tipe TANDUR berbantuan permainan tradisional terhadap hasil belajar siswa kelas IV SD Gugus V Kecamatan Buleleng Tahun Ajaran 2019/2020. $\mathrm{H}_{1}=$ Terdapat pengaruh yang signifikan implementasi model pembelajaran quantum teaching tipe TANDUR berbantuan permainan tradisional terhadap hasil belajar siswa kelas IV SD Gugus V Kecamatan Buleleng Tahun Ajaran $2019 / 2020$.

\section{Hasil dan pembahasan}

Data post-test hasil belajar IPA siswa eksperimen yang berjumlah 28 siswa dan pada siswa kontrol berjumlah 31 siswa. Adapun hasil analisis data statistik deskriptif hasil belajar IPA pada kelompok eksperimen dan kontrol disajikan pada tabel 2 .

Tabel 2. Deskripsi Data Hasil Belajar IPA Pada Kelompok Eksperimen dan Kelompok Kontrol

\begin{tabular}{ccc}
\hline Statistik & Kelompok Eksperimen & Kelompok Kontrol \\
\hline Skor Tertinggi & 93 & 87 \\
Skor Terendah & 60 & 53 \\
Mean & 78,79 & 70,40 \\
Standar Deviasi & 9,88 & 10,52 \\
Varians & 97,66 & 110,58 \\
\hline
\end{tabular}


Pada tabel di atas merupakan analisis data statistik deskriptif hasil belajar IPA, yang terdiri dari skor tertinggi dan terendah, mean (rata-rata), standar deviasi dan varians dari kelompok eksperimen dan kelompok kontrol. Dari data diatas terlihat bahwa rata-rata hasil belajar kelompok eksperiment lebih besar dibandigkan kelompok kontrol, sedangkan standar deviasi dan varian kelompok control lebih besar dibandingkan kelompok eksperimen.

Data akan disajikan dalam bentuk tabel, tetapi didahulukan untuk menentukan banyak kelas yaitu 6, rentang data yaitu 34 dan panjang kelas interval yaitu 6. Setelah menentukkan itu semua, akan terdapat data seperti tabel 3 dibawah ini.

Tabel 3. Distribusi Frekuensi Kelas Eksperimen

\begin{tabular}{|c|c|c|c|c|c|}
\hline Kelas Interval & Nilai Tengah (Xi) & fi & fk & Xi.fi & F.relatif \\
\hline $60-65$ & 62,5 & 3 & 3 & 187,50 & 10,71 \\
\hline $66-71$ & 68,5 & 4 & 7 & 274,00 & 14,29 \\
\hline $72-77$ & 74,5 & 6 & 13 & 447,00 & 21,43 \\
\hline $78-83$ & 80,5 & 6 & 19 & 483,00 & 21,43 \\
\hline $84-89$ & 86,5 & 3 & 22 & 259,50 & 10,71 \\
\hline $90-95$ & 92,5 & 6 & 28 & 555,00 & 21,43 \\
\hline \multicolumn{2}{|c|}{ Jumlah } & \multicolumn{2}{|c|}{28} & 2206,00 & 100,00 \\
\hline \multicolumn{2}{|c|}{ Mean } & \multicolumn{4}{|c|}{78,79} \\
\hline
\end{tabular}

Berdasarkan frekuensi hasil belajar IPA siswa yang dibelajarkan dengan model pembelajaran quantum teaching tipe TANDUR berbantuan permainan tradisional pada siswa kelas IV kelompok eksperimen. Kemudian dapat disajikan pada histogram seperti gambar 1 berikut.

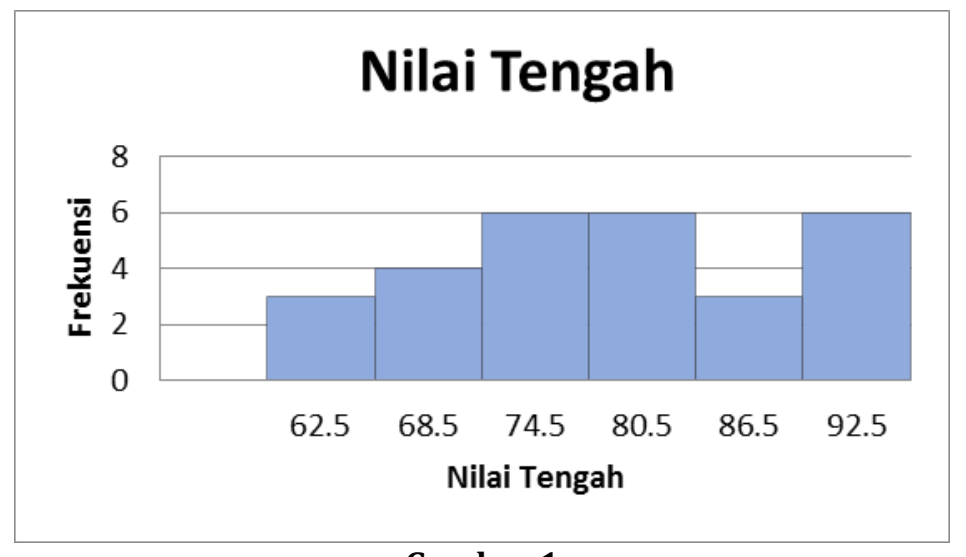

Gambar 1.

Histogram Data Post-Test Hasil Belajar IPA Siswa Kelompok Eksperimen

Setelah skor rata-rata belajar siswa dikonversikan dengan menggunakan rata-rata ideal dan standar deviasi ideal seperti dibawah ini, maka tentu saja dapat mengetahui tinggi dan rendahnya hasil belajar IPA siswa kelas IV. Rata-rata (M) adalah 78,79 dan diketahui rata-rata (X) skor hasil belajar IPA kelompok eksperimen terletak pada kategori Sangat Tinggi. Data akan disajikan dalam bentuk tabel, tetapi didahulukan untuk menentukan banyak kelas yaitu 6, rentang data yaitu 35 dan panjang kelas interval yaitu 6. Setelah menentukkan itu semua, akan terdapat data seperti tabel 4 dibawah ini.

Tabel 4. Distribusi Frekuensi Kelas Kontrol

\begin{tabular}{cccccc}
\hline Kelas Interval & Nilai Tengah (Xi) & Fi & $\mathbf{f k}$ & Xi.fi & F.relatif \\
$53-58$ & 55,5 & 5 & 5 & 277,50 & 16,13 \\
\hline
\end{tabular}




\begin{tabular}{|c|c|c|c|c|c|}
\hline $59-64$ & 61,5 & 6 & 11 & 369,00 & 19,35 \\
\hline $65-70$ & 67,5 & 5 & 16 & 337,50 & 16,13 \\
\hline $71-76$ & 73,5 & 4 & 20 & 294,00 & 12,90 \\
\hline $77-82$ & 79,5 & 6 & 26 & 477,00 & 19,35 \\
\hline 83-88 & 85,5 & 5 & 31 & 427,50 & 16,13 \\
\hline \multicolumn{2}{|c|}{ Jumlah } & \multicolumn{2}{|c|}{31} & 2182,50 & 100,00 \\
\hline \multicolumn{2}{|c|}{ Mean } & & & 70,40 & \\
\hline
\end{tabular}

Berdasarkan frekuensi hasil belajar IPA siswa yang diberikan perlakuan dengan pendekatan saintifik pada siswa kelas IV kelompok kontrol. Kemudian dapat disajikan pada histogram seperti gambar 2berikut.

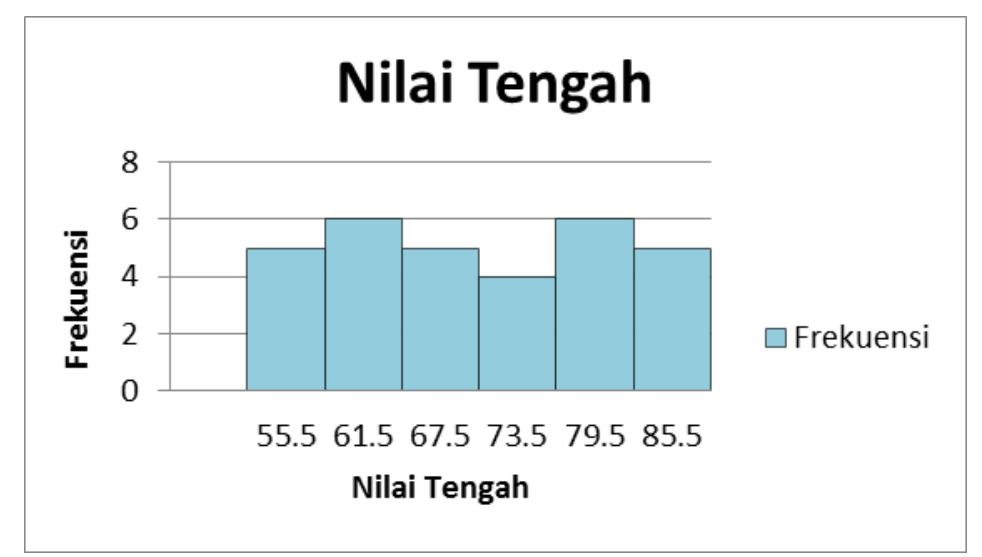

Gambar 2.

Histogram Data Post-Test Hasil Belajar IPA Siswa Kelompok Kontrol

Mengetahui hasil belajar siswa yang tinggi maupun yang rendah dengan cara yaitu dapat mengkonversikan dari rata-rata ideal dengan standar deviasi ideal. diketahui rata-rata (X) adalah 70,4 dan diperoleh bahwa skor hasil belajar IPA klompok kontrol terletak pada kategorikTinggi.

Sebelum melakukan uji hipotesis, maka harus dilakukan beberapa uji prasyarat, meliputi uji normalitas terhadap data tes hasil belajar IPA siswa. Uji normalitas ini dilakukan untuk membuktikan bahwa kedua sampel tersebut berdistribusi normal. Adapun hasil perhitungan yang didapatkan dengan menggunakan rumus Chi Squre, diperoleh $X^{2}$ hitung skor hasil belajar IPA siswa kelompokkeksperimen adalah 6,78 sedangkan $X^{2}$ tabel denganktaraf signifikan $5 \%$ dan $\mathrm{dk}=3$ adalah 7,81. Hal ini berarti $X^{2}$ hitung skor hasil belajar IPA siswa kelompok eksperimen lebih kecil daripada $X^{2}$ tabel $\left(X^{2}\right.$ hitung $<X^{2}$ tabel), sehingga data hasil belajar kelompok eksperimen berdistribusi normal. Selanjutnya, $X^{2}$ hitung skor hasil belajar IPA siswa kelompok kontrol adalah 6,26 sedangkan $X^{2}$ tabel dengan taraf signifikan 5\% dan $\mathrm{dk}=3$ adalah 7,81. Hal ini berarti $X^{2}$ hitung skor hasil belajar IPA siswa kelompok kontrol lebih kecil daripada $X^{2}$ tabel $\left(X^{2}\right.$ hitung $<X^{2}$ tabel), sehingga data hasil belajar kelompok eksperimen berdistribusiknormal.

Tabel 5. Rangkuman Hasil Uji Normalitas Distribusi Hasil Belajar IPA

\begin{tabular}{ccccc}
\hline No & $\begin{array}{c}\text { Kelpmpok Data Hasil Belajar } \\
\text { IPA }\end{array}$ & $X^{2}$ hitung & $\begin{array}{c}X^{2} \text { tabel dengan taraf } \\
\text { Signifikan } 5 \%\end{array}$ & Status \\
\hline 1 & Eksperimen & 6,78 & 7,81 & Normal \\
2 & Kontrol & 6,26 & 7,81 & Normal \\
\hline
\end{tabular}

Uji homogenitaskdilakukan terhadap varian pasangankantar kelompok eksperimenkdan kelompok kontrol. Uji yang digunakan adalah uji-Fkdengan kriteria data homogen jika data $F_{\text {hitung }}<F_{\text {tabel. }}$. Adapun diketahui $F_{\text {hitung }}$ skor hasil belajar IPA siswa kelompokkeksperimen dan kelompok kontroll adalah 1,12 sedangkan. Kemudian dibandingkan dengan $\mathrm{F}_{\text {tabel }}$ pada df pembilang $=30$ dan df penyebut $27 . \mathrm{F}_{\text {tabel }}=\mathrm{F}$ $(0,05 ; 30 ; 27)=1,88$. Karena $F_{\text {hitung }}<\mathrm{F}_{\text {tabel }}$ data posttest mempunyai varians yang sama atau homogen. 
Sesudah diperoleh hasil dari uji prasyarat analisis data, pada tahap berikutnya adalah dilanjutkan dengan pengujian hipoteses penelitian. Pengujian hipotesis tersebut dilakukan dengan menggunakan rumus $t$-test separated varians. Kriterianya, $\mathrm{H}_{0}$ ditolak jika $t_{\text {hitung }}>\mathrm{t}_{\text {tabel. }}$ Rangkuman uji hipotesis akan disajikan pada tabel dibawah ini.

Tabel 6. Ringkasan Hasil Pengujian Uji-t

\begin{tabular}{ccccccc}
\hline Kelompok Data Hasil Belajar IPA & Varians & $\mathrm{N}$ & $\mathrm{Db}$ & $\mathrm{t}_{\text {hitung }}$ & $\mathrm{t}_{\text {tabel }}$ & Kesimpulan \\
\hline Eksperimen & 97,65 & 28 & \multirow{2}{*}{57} & \multirow{2}{*}{3,21} & \multirow{2}{*}{2,00} & $\begin{array}{c}\mathrm{t}_{\text {hitung }}>\mathrm{t}_{\text {tabel }} \\
\text { Kontrol }\end{array}$ \\
\hline
\end{tabular}

Adapun hasil analisis uji-t (post-test) diperoleh $t_{\text {hitung }}=3,21$ sedangkanknilai $t_{\text {tabel }}$ pada taraf signifikan $5 \%$ dengan derajat kebebasan $(\mathrm{db})$ adalah $(\mathrm{n} 1+\mathrm{n} 2-2)=28+31-2=57$ adalah 2,00, Berdasarkan $\mathrm{t}_{\text {hitung }}$ $=3,21>\mathrm{t}_{\text {tabel }}=2,00$ maka $\mathrm{H}_{0}$ ditolak dan $\mathrm{H}_{1}$ diterima. Dengan demikian, dapat diinterprestasikan bahwa terdapat pengaruh yang signifikan implementasi model pembelajaran quantum teaching tipe TANDUR berbantuan permainan tradisional terhadap hasil belajar siswa kelas IV SD Gugus V Kecamatan Buleleng Tahun Ajaran 2019/2020. Perhitungan hasil Uji-t terdapat pada lampiran.

Rata-rata dari hasil belajar kelompokkeksperimen adalah 78,79 dan kelompok kontroll adalah 70,40. Maka lebih besar rata-rata kelompok eksperimen dibandingkan kelompok kontrol, jadi dapat disimpulkan bahwa penerapan model pembelajaran quantum teaching tipe TANDUR berbantuan permainan tradisional berpengaruh terhadap hasil belajar siswa kelas IV SD Gugus V Kecamatan Buleleng Tahun Ajaran 2019/2020

\section{Pembahasan}

Dalam penelitian yang penulis lakukan menunjukkan hasil bahwa model pembelajaran quantum teaching tipe TANDUR berbantuan permainan tradisional yang diterapkan di kelas eksperimen dan pendekatan saintifik yang diterapkan pada kelas kontrol dalam penelitian ini menunjukkan bahwa terdapat pengaruh yang berbeda pada hasil belajar IPA siswa kelas IV. Peninjauan ini didasarkan pada rata-rata skor hasil belajar siswa dan uji-t. Rata-rata skor hasil belajar yang mengikuti model quantum teaching adalah 78,79 dan rata- rata skor siswa yang mengikuti pendekatan saintifik adalah 70,4. Hal ini tanya jawab terkait hal-hal yang diberikan oleh pengajar. Dengan demikian, siswa dapat menyimpulkan materi yang telah peserta didik pelajari.

Pada penelitian ini juga menghasilkan suatu analisis data yang menggunakan uji-t, diketaui bahwa thitung yang diperoleh adalah 3,21 dan ttabel pada taraf 5\% adalah 2,00. Dari hasil perhitungan tersebut dapat diketahui bahwa t-hitung lebih besar daripada t-tabel, sehingga dapat disimpulkan bahwa penelitian ini adalah signifikan. Hal ini berarti, terdapat perbedaan hasil belajar antara kelompok siswa yang dibelajarkan dengan model quantum teaching tipe TANDUR berbantuan permainan tradidional dengan siswa yang dibelajarkan dengan pendekatan saintifik.

Terdapat suatu perbedaan hasil belajar antara kelompok eksperimen yang menggunakan model pembelajaran quantum teaching tipe TANDUR berbantuan permainan tradisional dan kelompok kontrol menggunakan pendekatan saintifik disebabkan bahwa model pembelajaran quantum teaching tipe TANDUR berbantuan permainan tradisional merupakann inovasi baru yang sangat menekankan gerak aktif dari siswa.

Quantum teaching menurut Bobby DePorter (dalam Fathurrohman, 2016:179) adalah pembaharuan yang akan mengembangkan cara baru/kegiatan baru bertujuan untuk memudahkan suatu kegiatan pembelajaran mencapai tujuan. Dalam model ini juga terdapat langkah yang menjadi acuan dalam guru melaksanakan pembelajaran, yaitu TANDUR yang terdiri dari tahap tumbuhkan, alami, namai, demontrasikan, ulangi dan rayakan. Langkah-langkah ini akan mampu dalam mengubah cara siswa belajar agar lebih peka dan terangsang oleh keadaan yang ada disekitar mereka jika berada di kelas atau di luar kelasnya. Quantum teaching adalah sebuah cara mengajar siswa yang aktif dan selalu ingin tampil pada saat pembelajaran karena dalam model pembelajaran quantum teaching ini akan lebih mengaktifkan indra mulai dari melihat, mendengar dan berbicara. (Yahya, 2017). Model quatum teaching mempunyai beberapa prinsip, menurut Dwi, Yahya, Ardian, (2019) prinsipnya antara lain: 1) semua orang berbicara, 2) semuanya terlibat dalam proses pembelajaran serta semua sumber belajar digunakan, 3) semua proses belajar mempunyai tujuan yang jelas, 4) pemberian sebuah sebuah rangsangan sangat penting dalam proses menumbuhkan rasa ingin tahu, hal ini lebih baik diberikan sebelum proses namai. 5) Akui setiap 
usaha. Apaun hasil yang ditunjukkan oleh siswa harus tetap di akui. 6) perayaan dalam proses pembelajaran adalah salah satu umpan balik yang bisa diberikan.

Menurut (DePoter, 2010:32) dalam Wahyu, dkk. (2016) menyatakan bahwa quantum teaching mempunyai kelebihan yaitu 1) model quantum teaching memberikan kesempatan kepada siswa untuk belajar sesaui dengan yang diinginkan. 2) model quantum teaching ini mengaitkan proses belajaran dengan apa yang dialami oleh siswa sehingga memberikan manfaat yang baik untuk siswa. 3) model quantum teaching mengajak siswa untuk aktif untuk melaksanakan pembelajarannya ini dapat dilihat dari segala gegiatan dalam proses pembelajaran baik itu memilih ide dalam proses pembelajaran sampai dengan evaluasi. dan 4) memberikan rasa nyaman siswa melalui penataan lingkungan belajar dengan mengatur posisi meja dan kursi dengan format yang dinamis. Hal lain yang lebih menonjol dari model Quantum Teaching terletak pada delapan kunci keunggulan yang juga digunakan dalam Quantum Teaching ini, yaitu: integritas (kejujuran), kegagalan awal kesuksesan, berbicara dengan niat yang positif, hidup di saat ini, komitmen, tanggung jawab, sikap luwes atau fleksibel, dan keseimbangan antar pikiran, tubuh dan jiwa.

Pada tahap tumbuhkan, hal yang harus dilaksanakan guru adalah membangkitkan rasa percaya diri siswa dalam melaksanakan pembelajaran dengan mengajak berdiskusi dan memotivasi siswa. Membangun semangat siswa dalam memulai suatu pembelajaran dengan cara bernyanyi bersama. Guru juga harus menumbuhkan minat siswa untuk mempelajari konsep dengan memberitahu manfaat yang didapat oleh siswa dalam mempelajari materi itu

Pada tahap alami, guru mengajak siswa membaca buku terlebih dahulu untuk memahami apa yang akan dipelajari. Setelah membaca, guru mengajak siswa untuk melakukan suatu permainan tradisional. Permainan ini sudah dirancang agar tetap terkait dengan pembelajaran yang akan dilaksanakan. Permainan yang dilakukan adalah permainan tradisional bola kasti, bola yang digunakan adalah bola kasti yang berwarna hijau. Dalam permainan, pengajar menggali pengetahuan siswa dengan bertanya setiap gerakan yang dialami oleh siswa. Seperti saat siswa berlari, bersentuhan langsung dengan lingkungan dan mengalami langsung apa yang terjadi.

Pada tahap namai, setelah guru mengajak siswa bermain dilanjutkan dengan memberikan sebuah LKPD yang terdapat beberapa soal yang harus didiskusikan oleh siswa dengan teman sebangkunya. Dalam berdiskusi guru juga menyelipkan beberapa kata kunci tentang konsep materi yang dipelajari oleh siswa. Karena semua siswa terlibat dalam sebuah permainan dan semua mengetahui apa saja yang terdapat dalam permainan bola kasti tersebut, maka diskusi yang dilakukan bisa membantu dalam mengerjakan soal yang telah diberikan.

Pada tahap demontrasikan, melalui tahap demontrasi ini siswa dapat bertukar pikiran dengan siswa yang lainnya dan manfaat lainnya siswa diajarkan untuk belajar mengemukakan pendapat tentang apa yang ia ketahui. Siswa secara bergilir membacakan hasil yang telah dikerjakan dan menginformasikan ke semua teman kelas dan guru. Dalam kesempatan ini, guru menjadi fasilitator untuk memandu kegiatan yang dilakukan oleh siswa, guru megarahkan siswa agar dapat menanggapi hal-hal yang telah disampaikan oleh siswa yang telah membacakan hasilnya di depan kelas.

Pada tahap ulangi, guru melakukan pengulangan materi dan memberikan permasalahan yang lebih kompleks sehingga pengetahuan yang didapatkan oleh siswa menjadi lebih gampang diingat oleh daya ingat siswa. Guru mengajak siswa juga untuk melakukan interaksi tanya jawab terkait hal-hal yang diberikan oleh pengajar. Dengan demikian, siswa dapat menyimpulkan materi yang telah peserta didik pelajari.

Pada tahap rayakan, ini merupakan tahap terakhir. Guru mengadakan perayaan bagi siswa untuk mendorong siswa agar lebih semangat lagi dalam belajar. Perayaan yang dilakukan guru disini adalah dengan pemberian reward yang berupa tepuk tangan/aplause, ucapan yang memotivasi ataupun bisa memberikan sebuah hadiah yang berguna bagi siswa.

Seperti yang dilakukan oleh Himmatul Ulya dan Ratri Rahayu pada penelitian yang berjudul Pembelajaran Treffinger Berbantuan Permainan Tradisional Congklak Untuk Meningkatkan Kemampuan Komunikasi Matematis oleh Himmatul Ulya dan Ratri Rahayu yang memperoleh hasil yaitu adanya peningkatan kemampuan komunikasi matematis peserta didik pada kategori rendah sebanyak 4 peserta didik (9,76\%), kategori sedang sebanyak 16 peserta didik (39,02\%), dan kategori tinggi sebanyak 21 peserta didik (51,22\%). Secara klasikal peningkatan kemampuan komunikasi matematis peserta didik sebesar 0,65 atau 65\% yang berarti bahwa rata-rata peningkatan kemampuan komunikasi matematis peserta didik termasuk dalam kategori sedang. quantum teaching antara lain pada penelitian yang berjudul Penerapan model quantum teaching untuk meningkatkan kualitas pembelajaran pada mata pelajaran IPS kelas V MI Islamiyah Kebonsari Kota Malang oleh Evy Rosalina Susanti yaitu hasil penelitian menunjukkan bahwa penerapan model Quantum Teaching pada pembelajaran IPS telah berhasil meningkatkan hasil belajar siswa kelas V MI Islamiyah Kebonsari. Hal ini dilihat dari perolehan hasil 
belajar siswa terus meningkat mulai dari rata-rata sebelumnya $(65,15)$ mengalami paningkatan pada siklus I dengan rata-rata kelas sebesar $(70,90)$ dan prosentase ketuntasan belajar kelasnya yaitu $(68,75)$ meningkat pada siklus II dengan rata-rata kelasnya sebesar $(80,56)$ dan prosentase ketuntasan belajar kelasnya sebesar (81,25\%). Disarankan untuk peneliti selanjutnya dapat memperbaiki kelemahankelemahan yang ada sehingga pembelajaran diharapkan berjalan seoptimal mungkin.

Berdasarkan hasil penelitian, dengan penggunaan model pembelajaran quantum teaching tipe TANDUR ini pada kelas eksperimen di SD Gugus V Kecamatan Buleleng memberikan dampak yang baik. Hasil penelitian yang diperoleh bisa memberikan suatu tolak ukur dalam pertimbangan model pembelajaran yang digunakan agar dapat memperoleh hasil belajar yang lebih memuaskan dibandingkan sebelumnya.

\section{Simpulan dan saran}

Dari hasill penelitian dan pembahasan dapat disimpulkan bahwa terdapat pengaruh hasil belajar IPA antara kelompok siswa yang dibelajarkan dengan pembelajaran quantum teaching tipe TANDUR berbantuan permainan tradisional dan kelompok siswa yang dibelajarkan dengan pembelajaran pendekatan saintifik pada siswa kelas IV SD di Gugus V Kecamatan Buleleng tahun pelajaran 2019/2020. Jadi, pembelajaran quantum teaching tipe TANDUR berbantuan permainan tradisional berpengaruh pada siswa kelas IV SD di Gugus V Kecamatan Buleleng, tahun pelajaran 2019/2020. Berdasarkan hasil penguji hipotesis, diperoleh bahwa $t_{\text {hiung }}$ adalah 3,21 lebih besar dari $t_{\text {tabel }}$ dengan $\mathrm{db}=57$ pada taraf signifikan $5 \%$ adalah 2,00. Hal ini berarti $t_{\text {hitung }}$ lebih besar dibandingkan $\mathrm{t}_{\text {tabel, }}$ sehingga $\mathrm{H}_{0}$ ditolak dan $\mathrm{H}_{1}$ diterima.

Berdasarkan hasil penelitian yang telah dilakukan, saran yang dapat disampaikan adalah sebagai berikut: 1) Bagi Guru, guru hendaknya memperhatikan karakteristik siswa dan guru juga dapat menggunakan sebuah model pembelajaran yang baik serta berinovasi dalam proses pembelajaran yang bertujuan agar siswa tidak mudah bosan dan kehilangan konsentrasi, 2) Bagi Kepala Sekolah, hendaknya kepala sekolah memfasilitasi kemampuan guru dalam menyediakan pembelajaran yang optimal dengan mengikut sertakan dalam seminar atau pelatihan mengenai pembelajaran inovatif. Selain itu, kepala sekolah juga bisa menambah sumber atau bahan pelajaran untuk siswa di sekolah, 3) Bagi Peneliti Lain, dalam penelitian ini, peneliti hanya menekankan pada hasil belajar ranah kognitif. Ranah afektif dan psikomotor belum dijabarkan pada penelitian ini. Maka dari itu penelitian lain mungkin dapat melaksanakan penelitian lanjutan mengenai ranah-ranah tersebut.

\section{Daftar Rujukan}

Agung, A. G. A. (2016). Statistik Dasar untuk Pendidikan. Yogyakarta: Deepublish.

Azizah, I. M. (2016). Efektivitas Pembelajaran Menggunakan Permainan Tradisional Terhadap Motivasi Dan Hasil Belajar Materi Gaya Di Kelas IV Min Ngronggot Nganjuk. Dinamika Penelitian, 16.

Bundu, P. (2006). Penilaian Keterampilan Proses Dan Sikap Ilmiah Dalam Pembelajaran Sains Sekolah Dasar. Jakarta: Direktorat Ketenagakerjaan.

Candiasa, I. M. (2010). Pengujian Instrumen Penelitian Disertai Aplikasi ITEMAN dan BIGSTEPS. SingarajaBali: Universitas Pendidikan Ganesha.

Dantes, N. (2017). Desain Eksperimen Analisis Data. Depok: Rajawali Pers.

DePoter, B. (2010). Quantum Teaching. Bandung: Kaifa.

Devi, Frita Asriyanti dan Lilis Arinatul Janah. 2018. Analisis Gaya Belajar Ditinjau dari Hasil Belajar Siswa. Ilmu Pendidikan: Jurnal Kajian Teori dan Praktik Kependidikan Volume 3, Nomor 2, Desember 2018. http://journal2.um.ac.id/index.php/jktpk/article/view/5021/3530.

Dwi Cahyaningrum, Yahya AD , dan Ardian Asyhari. 2019. Pengaruh Model Pembelajaran Quantum Teaching Tipe Tandur Terhadap Hasil Belajar. Indonesian Journal of Science and Mathematics $\begin{array}{lllll}\text { Education } & 02 & (3) & \text { 372-379. }\end{array}$ http://ejournal.radenintan.ac.id/index.php/IJSME/article/view/4363/2818

Fathurrohman, M. (2016). Model-Model Pembelajaran Inovatif. Jogjakarya: AR-RUZZMEDIA. 
Hakimeh Akbar et al. Iranian Journal of Pediatrics Volume 19 No. 2, Juni 2009: 123-129. The Effect of Traditional Games in Fundamental Motor Skill Development in 7-9 Years Old Boys. Iran.

Koyan, I. W. (2012). Statistik Pendidikan. Singaraja-Bali: Universitas Pendidikan Ganesha Press.

Lukad, Valiant Perdana Sutrisno dan Budi Tri Siswanto. 2016. Faktor-Faktor Yang Mempengaruhi Hasil Belajar Siswa pada Pembelajaran Praktik Kelistrikan Otomotif SMK di Kota Yogyakarta. Jurnal Pendidikan Vokasi Volume 6, No 1, Februari 2016 (111-120) https://journal.uny.ac.id/index.php/jpv/article/view/8118/6872

Malawi, I., \& Juwarti. (2013). Pengaruh Pembelajaran Cooperatif Learning Type Make A-Match Terhadap Hasil Belajar Ipa Kelas V Sdn 01 Manisrejo Kota Madiun. Journal of Chemical Information and Modeling, 53(9), 1689-1699. https://doi.org/10.1017/CB09781107415324.004

Maolani, R. A., \& Cahyana, U. (2016). Metodelogi Penelitian Pendidikan. Jakarta: PT. Raja Grafindo Persada.

Maunah, B. (2009). Ilmu Pengetahuan. Yogjakarta: Sukses Offset.

Mega , Gustiana Anggitaa, Siti Baitul Mukarromahb dan Mohammad Arif Ali. 2018. Eksistensi Permainan Tradisional Sebagai Warisan Budaya Bangsa. JOURNAL OF SPORT SCIENCE AND EDUCATION $\begin{array}{llllll}\text { (JOSSAE) VOL: } & 3, & \text { NO: } & 2 & \text { OCTOBER } & \text { (2018). }\end{array}$ https://journal.unesa.ac.id/index.php/jossae/article/download/3392/2421

Samsuni. (2017). Penulis adalah Kasubbag Keuangan pada Fakultas Syariah dan Ekonomi Islam UIN Antasari Banjarmasin. [? 113. Manajemen Sumber Daya Manusia, 17 no 31(31), 113-124. Retrieved from http://ejurnal.staialfalahbjb.ac.id/index.php/alfalahjikk/article/view/19

Supramono, Agus. 2016. Pengaruh Model Pembelajaran Quantum (Quantum Teaching) Terhadap Hasil Belajar Ipa Siswa Kelas III SD YPS Lawewu Kecamatan Nuha Kabupaten Luwu Timur. Jurnal Nalar Pendidikan Volume 4, Nomor 2, Jul-Des 2016 ISSN: 2339-0749. http://ojs.unm.ac.id/nalar/article/download/2401/1886

Ulya, H., \& Rahayu, R. (2017). Pembelajaran Treffinger Berbantuan Permainan Tradisional Congklak Untuk Meningkatkan Kemampuan Komunikasi Matematis. AKSIOMA: Jurnal Program Studi Pendidikan Matematika, 6(1), 48-55.

Wahyu Merthayasa, Ketut Adnyana Putra dan I Nengah Suadnyana. (2016). Penerapan Model Quantum Teaching Untuk Meningkatkan Hasil Belajar Bahasa Indonesia (Keterampilan Menulis) Pada Siswa Kelas IV SD. e-Journal PGSD Universitas Pendidikan Ganesha Jurusan PGSD Vol: 4 No: 1 Tahun: 2016. https://ejournal.undiksha.ac.id/index.php/JJPGSD/article/download/7551/5159

Yahya, Husniyati. 2017. Pengaruh Penerapan Model Pembelajaran Quantum Teaching Terhadap Hasil Belajar Biologi Siswa SMA Islam Terpadu Al-Fityan Gowa. Jurnal Biotek Volume 5 Nomor 1 Juni 2017 hal. 155-166. http://journal.uin-alauddin.ac.id/index.php/biotek/article/view/3455/3248. 